\title{
New data on the crab spider genus Xysticus C.L. Koch, 1835 from the Altai, South Siberia (Aranei: Thomisidae)
}

\author{
Новые данные о пауках-крабах из рода Xysticus C.L. Koch, 1835 \\ с Алтая, Южкная Сибирь (Aranei: Thomisidae)
}

\author{
Alexander A. Fomichev \\ А.А. Фомичев \\ Altai State University, Lenina Prospect, 61, Barnaul, 656049, Russia. E-mail: a.fomichov@mail.ru \\ Алтайский государственный университет, проспект Ленина, 61, Барнаул, 656049, Россия.
}

KEY WORDS: Spiders, Aranei, Thomisidae, Xysticus, new species, new faunistic record, the Altai, Russia.

КЛЮчЕВЫЕ СЛОВА: Пауки, Aranei, Thomisidae, Xysticus, новый вид, новая фаунистическая находка, Алтай, Россия.

ABSTRACT: A new species Xysticus novokhatskyii sp.n. from the Altai (South Siberia) is described on the basis of both sexes. The new species is closely related to X. tyshchenkoi Marusik et Logunov, 1995 from Middle Asia, which is also illustrated. $X$. mongolicus Schenkel, 1963 is recorded from the Russian Altai for the first time.

РЕЗЮМЕ: С Алтая (Южная Сибирь) по обоим полам описан новый вид Xysticus novokhatskyii sp.n. Новый вид близок к $X$. tyshchenkoi Marusik et Logunov, 1995 из Средней Азии, последний также проиллюстрирован. Xysticus mongolicus Schenkel, 1963 впервые указывается для Русского Алтая.

\section{Introduction}

Crab spiders (Thomisidae) are among the most thoroughly studied groups of spiders in South Siberia, including the Altai Mountains and the adjacent Republic of Tuva. Main data about the crab spiders of the mountains of South Siberia are contained in numerous taxonomic and faunistic papers, of which the most important are as follows: Azarkina \& Trilikauskas [2013], Danilov [1993], Fomichev et al. [2014], Logunov [1995], Logunov \& Marusik [1994, 1998], Logunov et al. [1998], Marusik et al. [2000], Marusik [1989], Marusik \& Logunov [2002], Simon [1895], Utochkin \& Savelyeva [1995]. Despite the fact that the crab spiders of South Siberia are well-studied, there are certain gaps in our knowledge. For instance, among 75 species known from the region at hand, the records of 15 of them are indicated as doubtful [Mikhailov, 2013]. Yet, 13 species recorded from the northern part of Central Asia remain known from females only. One of the species - Xysticus altaicus Simon, 1895 - is not even illustrated yet. While studying newly collected materials from the south-east part of the Russian Altai, a species new to science and a species new to the
Russian part of Altai have been found.

The goals of this paper are as follows: (1) to describe a new species Xysticus novokhatskyii sp.n.; (2) to provide comparative figures for its close relative $X$. tyshchenkoi Marusik et Logunov, 1995; and (3) to report on a new faunistic record from the Altai for Xysticus mongolicus Schenkel, 1963.

\section{Material and methods}

The paper based on the new material collected by the author during field trips to the Altai in July 2012, 2013 and 2014. The material was collected from the Kuraisky and Chikhacheva Mt. Ranges, adjacent to the Chuiskaya Steppe. The studied area belongs to the south-east Altai lying in Kosh-Agach District of the Republic of Altai (Russia).

Photographs were taken in a dish with paraffin on its bottom. Specimens were photographed using AxioCam MRc5 (Zeiss) camera attached to a Stemi 2000 - C stereomicroscope. Digital images were prepared using Helicon focus 3.10 image staking software. Epigynes were macerated in $\mathrm{KOH}$ solution. All measurements are given in millimeters. While describing the leg spination, apical spines on metatarsi were not counted.

Abbreviations used in the text are as follows: Leg segments: Fm - femur, Pa - patella, Mt - metatarsus, Ta - tarsus. Leg spination: d - dorsal, p prolateral, r - retrolateral, v — ventral. Eye sizes and inter-distances: ALE - anterior lateral eyes, AME anterior median eyes, MOA - median ocular area, MOA-L - length of MOA, MOA-WA - anterior width of MOA, MOA-WP - posterior width of MOA, PLE - posterior lateral eyes, PME - posterior median eyes. Museums: ISEA - Museum of Institute for Systematic and Ecology of Animals, Novosibirsk, Russia (curator: G.N. Azarkina); ZMMU - Zoological Museum of the Moscow State University, Russia (curator: K.G. Mikhailov). 


\section{Results}

\section{Xysticus novokhatskyii sp.n.}

Figs 1-2, 6, 7-9, 16-17, 20-23.

TYPES. Holotype $\sigma^{7}$ (ISEA, 001.7770) from Russia, Altai Republic, Kosh-Agach Distr., Kuraisky Mt. Range, near Tydtuyaryk Mt. $\left(50^{\circ} 08^{\prime} \mathrm{N}, 88^{\circ} 27^{\prime} \mathrm{E}\right), 3100-3280 \mathrm{~m}$ a.s.1., mountain stony tundra (goltsy), 12.07.2013, A.A. Fomichev. PARATYPES: $1 \sigma^{7}, 7$ 우 (ISEA, 001.7770), together with the holotype; 4 우 (ISEA, 000.7771), same locality, 2900-3300 m. a.s.1., mountain stony tundra (goltsy) and scree, 25.07.2012, A.A. Fomichev; $2 \Im^{\top} \sigma^{\top}, 1$ juv. (ZMMU), same republic and distr., Chikhacheva Mt. Range, Talduair Massive, Sailyugem Mt. (50 $\left.00^{\prime} \mathrm{N}, 8^{\circ} 18^{\prime} \mathrm{E}\right), 3300-3350$ $\mathrm{m}$ a.s.1., mountain stony tundra (goltsy), 3.07.2013, A.A. Fomichev; 1 (ZMMU), Chikhacheva Mt. Range, Talduair Massive, cirque near the origins of Talduairy River $\left(49^{\circ} 58^{\prime} \mathrm{N}, 89^{\circ} 17^{\prime} \mathrm{E}\right), 3000 \mathrm{~m}$ a.s.1., moraine, 1.07.2014, A.A. Fomichev.

ETYMOLOGY. The species is named in honour of my friend Yuri A. Novokhatskyi (Aktash, Russia) who helped a lot in the organization of fieldtrips to the Altai for collecting spiders and insects.

DIAGNOSIS. The new species is most similar to $X$. tyshchenkoi from Middle Asia (Figs 3-4, 10-12, 1819), and to the Palaearctic species $X$. ninnii Thorell, 1872 and $X$. sabulosus Hahn, 1832. It can be distinguished from $X$. tyshchenkoi by the straight embolus (slightly convoluted in X. tyshchenkoi) and by the absence of swelling of the retrolateral cymbial margin (swollen retrolateral margin in X. tyshchenkoi) in the males and by the comparatively narrow epigynal septum $(E s)$ with almost parallel edges and the shape of receptacles in the females. The new species can be separated from $X$. ninnii and $X$. sabulosus by the recurved tutaculum (Tt) (protruding forward in both species) and the shape of tibial apophysis in the males (cf. figs 2a-e in Utotchkin \& Savelyeva [1995] and figs 435a-g in Almquist [2006], respectively). The female of $X$. novokhatskyii sp.n. readily differs from those of $X$. ninnii and $X$. sabulosus in having the developed, convex epigynal septum. Both sexes of $X$. novokhatskyii sp. n. differ from all of the aforementioned species in the body coloration (Figs 1-2).

DESCRIPTION. Male (holotype). Total length 6.70. Carapace: 3.50 long, 3.10 wide. Clypeus 0.31 height, chelicera 1.05 long. Eye sizes and inter-distances: MOA-WA 0.57, MOA-WP 0.56, MOA-L 0.63, AME 0.10, ALE 0.20, PME 0.09, PLE 0.16, AME-AME 0.40, AME-ALE 0.23, PME-PME 0.39, PME-PLE 0.54. Coloration. Carapace dark brown, medially with Ushaped yellow spot. Clypeus, ocular area and chelicerae yellow-brown. Sternum yellow-brown, with brown edging and dark dots at the bases of setae. Maxillae and labium yellow-grey. Palps yellow-brown. Legs: coxae yellow-grey; femora yellow-brown, with dark dots at the bases of setae; patellae, tibiae, metatarsi and tarsi yellow. Patellae and tibiae dorsally with two longitudinal brown stripes. Legs of live spiders look metallic greenish. Abdomen: dorsum brown, with no pattern; sides whitish; venter, book lungs and spinnerets yellow-grey. Some specimens can have a darker coloration than that described above.
Leg measurements:

\begin{tabular}{|c|c|c|c|c|c|c|}
\hline Leg & Femur & Patella & Tibia & Metatarsus & Tarsus & Total \\
\hline I & 3.3 & 1.55 & 2.6 & 2.5 & 1.2 & 11.15 \\
\hline II & 3.45 & 1.55 & 2.65 & 2.55 & 1.2 & 11.4 \\
\hline III & 2.85 & 1.2 & 1.95 & 1.8 & 1.0 & 8.8 \\
\hline IV & 2.85 & 1.2 & 2.1 & 2.1 & 1.1 & 9.35 \\
\hline
\end{tabular}

Leg spination:

\begin{tabular}{|l|l|l|l|l|}
\hline Leg & Femur & Patella & \multicolumn{1}{|c|}{ Tibia } & Metatarsus \\
\hline I & $\mathrm{d} 9$ & $\mathrm{p} 1-0$ & $\mathrm{~d} 1-1-0$ & $\mathrm{p} 2-1-1-0$ \\
& $\mathrm{p} 24$ & $\mathrm{r} 1-0$ & $\mathrm{p} 2-1-1-1-1-1$ & $\mathrm{r} 2-1-1-0$ \\
& & & $\begin{array}{l}\mathrm{r} 1-1-1-1-1-1 \\
\mathrm{v} 2-2-1-2-2\end{array}$ & $\mathrm{v} 2-2-0-2$ \\
\hline II & $\mathrm{d} 19$ & $\mathrm{p} 1-0$ & $\mathrm{~d} 1-1-0$ & $\mathrm{p} 2-1-1-0$ \\
& & $\mathrm{r} 1-0$ & $\mathrm{p} 2-1-1-1-1$ & $\mathrm{r} 2-1-1-0$ \\
& & & $\mathrm{r} 1-1-1-1-1-1$ & $\mathrm{v} 1-2-2-0-2$ \\
& & $\mathrm{v} 2-2-2-2-1$ & \\
\hline III & $\mathrm{d} 12$ & $\mathrm{p} 0-1$ & $\mathrm{~d} 1-1-0$ & $\mathrm{~d} 0-1-2$ \\
& & $\mathrm{r} 1-0$ & $\mathrm{p} 1-2-1-2-2-1$ & $\mathrm{p} 2-1-1-0$ \\
& & & $\mathrm{r} 2-2-2-2-1$ & $\mathrm{r} 2-1-1-0$ \\
& & $\mathrm{v} 1-2-1-2-0-2$ & $\mathrm{v} 2-2-0$ \\
\hline IV & $\mathrm{d} 10$ & $\mathrm{p} 1-0$ & $\mathrm{~d} 1-1-0$ & $\mathrm{~d} 0-0-2$ \\
& & $\mathrm{r} 2-0$ & $\mathrm{p} 2-1-2-1-2-0$ & $\mathrm{p} 2-1-1-0$ \\
& & & $\mathrm{r} 2-1-2-1-2-1-1$ & $\mathrm{r} 2-2-1-0$ \\
& & & $\mathrm{v} 2-2-0-2$ & $\mathrm{v} 2-2-0$ \\
\hline
\end{tabular}

Palps as in Figs 7-9, 20-21, with two tibial apophysis: the retrolateral one $(R a)$ broad and rounded, the ventral one $(\mathrm{Va})$ with a rolled tip. Tegulum without apophysis, but with a small ridge. Embolus short with straight and pointed tip. Tutaculum membranous, bent in the proximal direction.

Female. Total length 7.5. Carapace: 3.5 long, wide 3.25. Clypeus 0.36 height, chelicera 1.0 long. Eye sizes and inter-distances: MOA-WA 0.61, MOA-WP 0.59, MOA-L 0.66, AME 0.11, ALE 0.21, PME 0.09, PLE 0.14, AMEAME 0.41, AME-ALE 0.26, PME-PME 0.41, PME-PLE 0.61. Coloration. Carapace as in the male, but lighter. Clypeus, ocular area, chelicerae and sternum as in the male. Maxillae yellow. Labium yellow-grey. Sternum yellow, with brown margins. Palps yellow. Legs yellow with dark dots at the bases of setae. Femora, patellae and tibiae with two longitudinal brown stripes dorsally. Abdomen: dorsum grey, with unclear pattern; sides whitish; venter cream-grey. Book lungs and spinnerets yellow-brown.

Leg measurements:

\begin{tabular}{|c|c|c|c|c|c|c|}
\hline Leg & Femur & Patella & Tibia & Metatarsus & Tarsus & Total \\
\hline I & 3.45 & 1.65 & 2.55 & 2.2 & 1.1 & 10.95 \\
\hline II & 3.65 & 1.65 & 2.6 & 2.3 & 1.1 & 11.3 \\
\hline III & 2.9 & 1.3 & 1.9 & 1.65 & 1.0 & 8.75 \\
\hline IV & 2.95 & 1.25 & 2.15 & 2.05 & 1.15 & 9.55 \\
\hline
\end{tabular}

Leg spination:

\begin{tabular}{|l|l|l|l|l|}
\hline Leg & Femur & Patella & \multicolumn{1}{|c|}{ Tibia } & Metatarsus \\
\hline I & $\mathrm{p} 0-3-0-1-0$ & 0 & $\mathrm{~d} 1-1-0$ & $\mathrm{p} 2-1-1-1-0$ \\
& & & $\mathrm{v} 1-2-2-2-1-1$ & $\begin{array}{l}\text { r2-1-1-2-0 } \\
\text { v1-2-2-2 }\end{array}$ \\
\hline II & $\mathrm{d} 1-1-1-0$ & 0 & $\mathrm{~d} 1-1-0$ & $\mathrm{p} 1-2-2-1-0$ \\
& & & $\mathrm{v} 2-1-2-2-2$ & $\begin{array}{l}\text { r2-1-1-0 } \\
\mathrm{v} 2-2-2-2\end{array}$ \\
\hline III & $\mathrm{d} 0-1-1-0$ & 0 & $\mathrm{~d} 1-1-0$ & $\mathrm{~d} 0-0-1$ \\
& & & $\mathrm{p} 1-0-1$ & $\mathrm{p} 2-2-1-1$ \\
& & & $\mathrm{r} 0-0-1$ & $\mathrm{r} 2-1-1-0$ \\
& & & $\mathrm{v} 1-2-2$ & $\mathrm{v} 2-2-0$ \\
\hline IV & $\mathrm{d} 0-1-0-0$ & $\mathrm{r} 1-0$ & $\mathrm{~d} 1-1-0$ & $\mathrm{p} 1-1-1-0$ \\
& & & $\mathrm{p} 1-0-1$ & $\mathrm{r} 1-0-1-0$ \\
& & & $\mathrm{r} 1-0-1$ & $\mathrm{v} 1-2-0$ \\
& & & $\mathrm{v} 2-2-2$ & \\
\hline
\end{tabular}



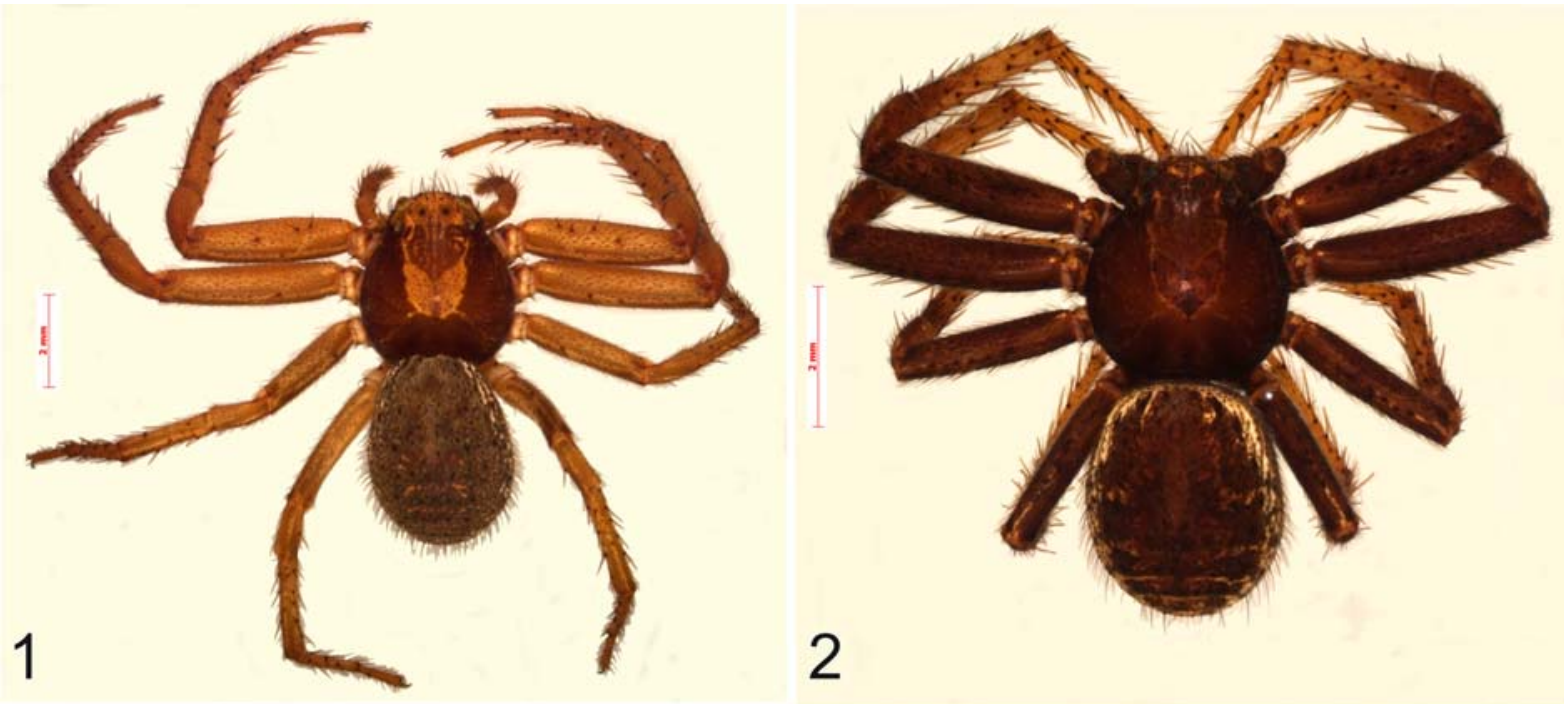

3
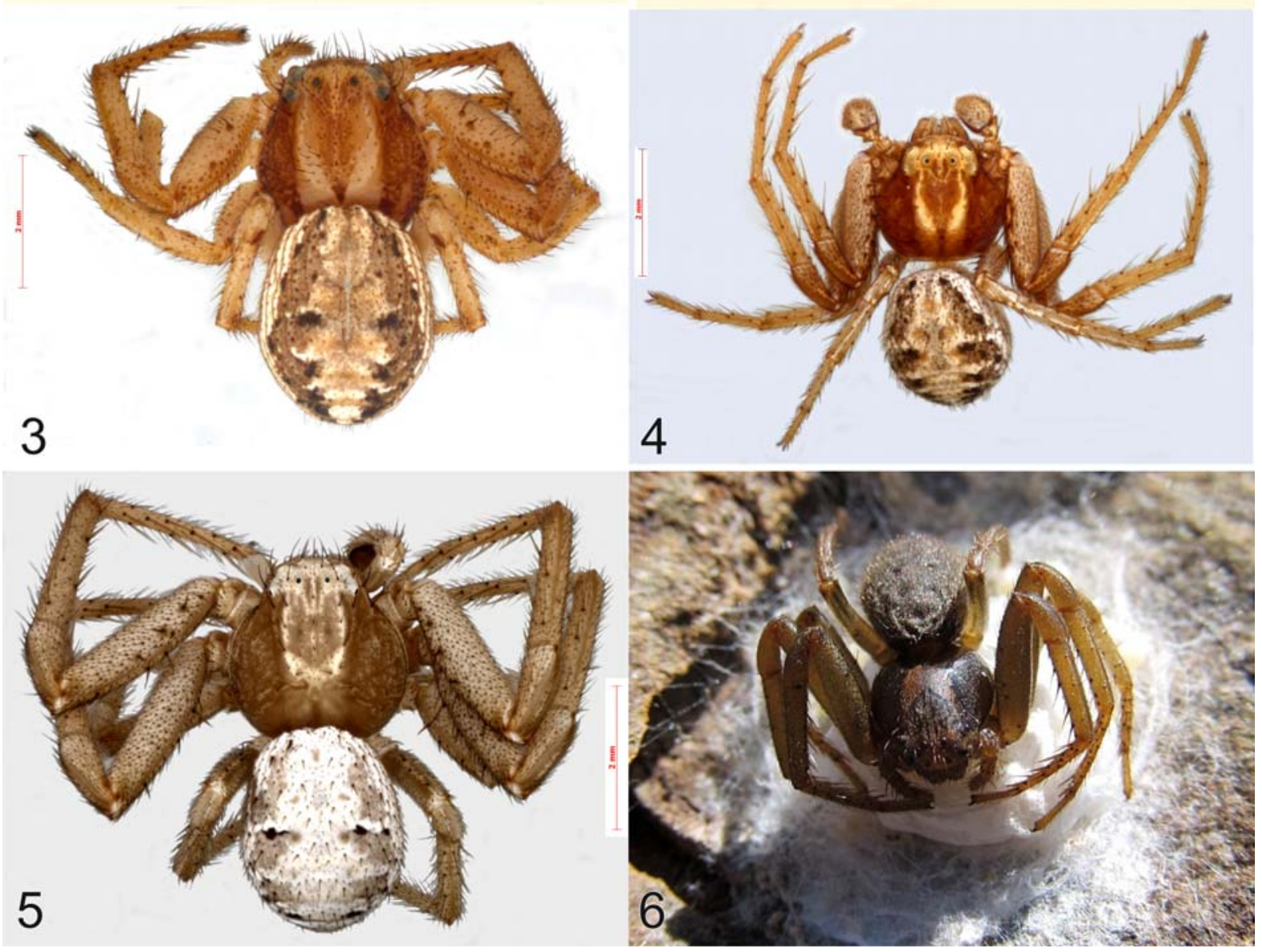

Figs 1-6. Habitus of Xysticus novokhatskyii sp.n. (1-2, 6), X. tyshchenkoi (3-4) and X. mongolicus (5), dorsal view. 1, 3 - female; 2 , 4-5 - male; 6 - female guarding the egg-cocoon. Scale $2 \mathrm{~mm}$.

Рис. 1-6. Габитус Xysticus novokhatskyii sp.n. (1-2, 6), X. tyshchenkoi (3-4) и X. mongolicus (5), вид сверху. 1, 3 — самка; 2, 45 - самец; 6 - самка охраняющая свой кокон. Масштаб 2 мм. 

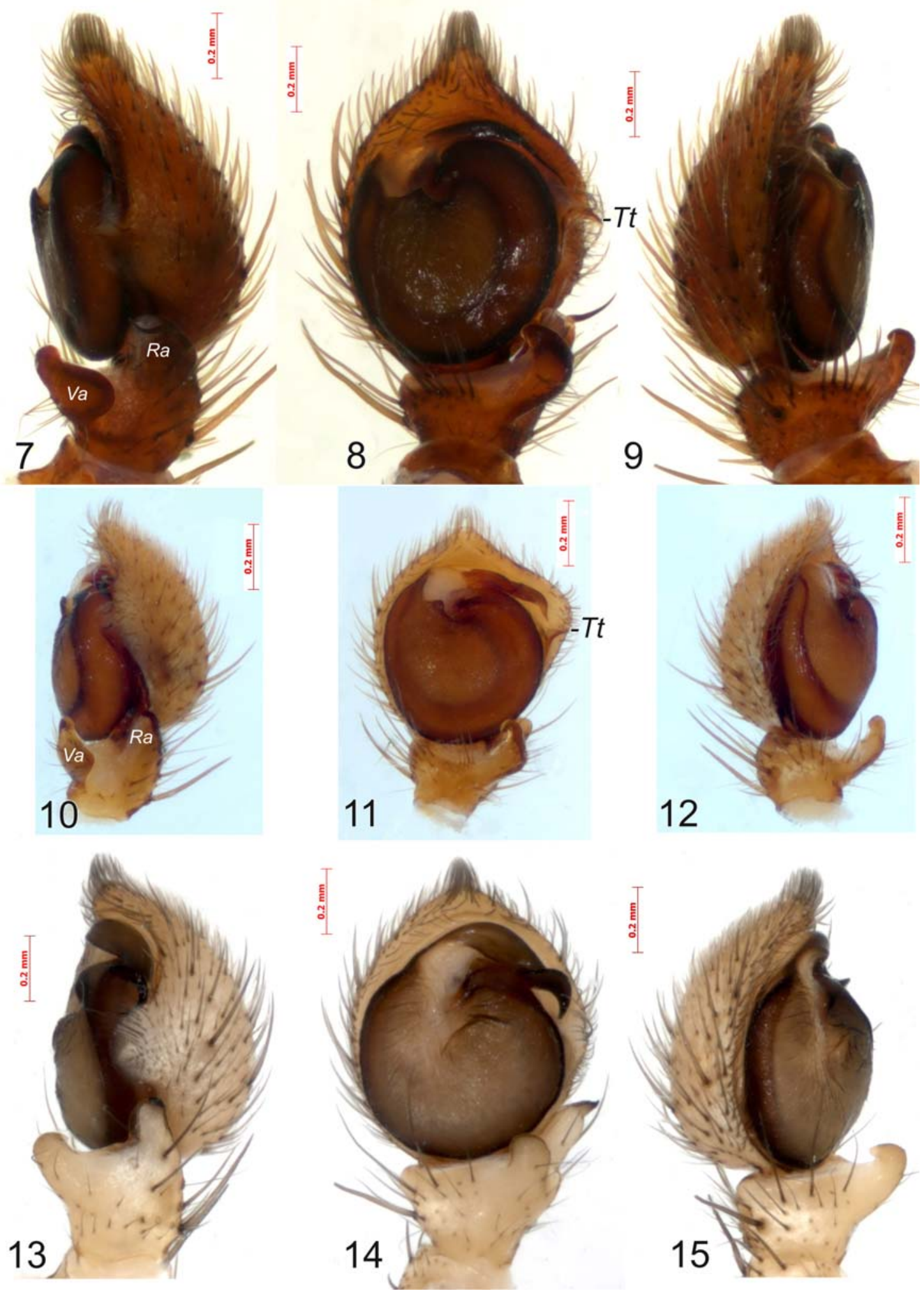

Figs 7-15. Male palps of Xysticus novokhatskyii sp.n. (7-9), X. tyshchenkoi (10-12) and X. mongolicus (13-15). 7, 10, 13 retrolateral view; $8,11,14$ - ventral view; $9,12,15$ - prolateral view. Scale $0.2 \mathrm{~mm}$. Abbreviations: $R a$ - retrolateral tibial apophysis, $\mathrm{Tt}$ - tutaculum, $\mathrm{Va}$ - ventral tibial apophysis.

Рис. 7-15. Пальпы самцов Xysticus novokhatskyii sp.n. (7-9), X. tyshchenkoi (10-12) и X. mongolicus (13-15). 7, 10, 13 - вид ретролатерально; 8, 11, 14 - вид вентрально; 9, 12, 15 - вид пролатерально. Масштаб 0,2 мм. Сокращения: Ra - ретролатеральный тибиальный отросток, $T t$ - тутакулюм, $\mathrm{Va}$ - вентральный тибиальный отросток. 


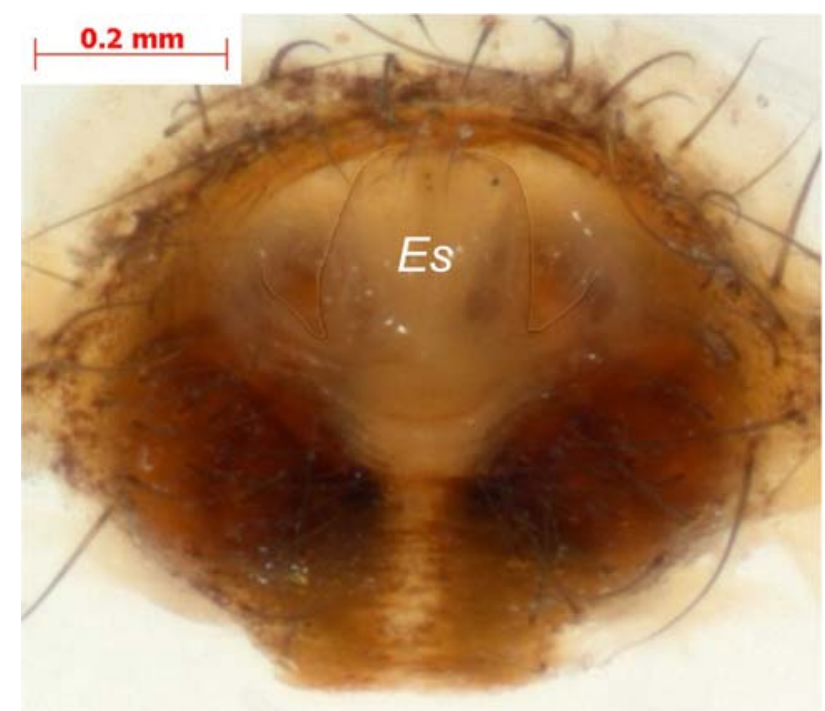

\section{6}
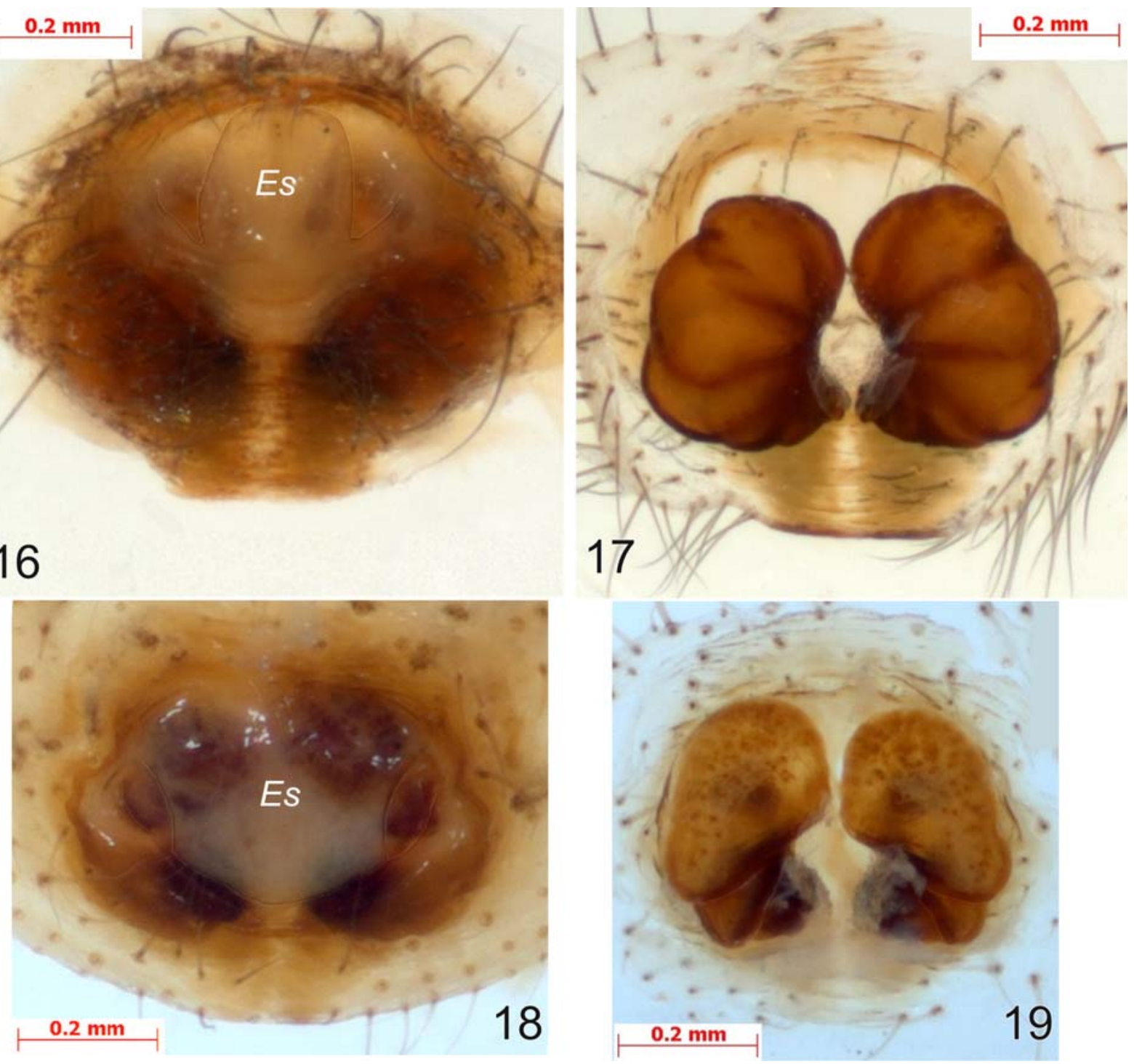

Figs 16-19. Epigynes of Xysticus novokhatskyii sp.n. (16-17) and X. tyshchenkoi (18-19). 16, 18 - ventral view; 17, 19 receptacles, dorsal view. Scale $0.2 \mathrm{~mm}$. Abbreviation: Es — epigynal septum.

Рис. 16-19. Эпигины Xysticus novokhatskyii sp.n. (16-17) и X. tyshchenkoi (18-19). 16, 18 - вид снизу; 17, 19 — рецептакулы, вид сверху. Масштаб 0,2 мм. Сокращение: $E s$ - септум.

Epigyne as in Figs 16-17, 22-23, without a distinct fovea. Septum well developed, with almost parallel margins. Receptacles kidney-shaped.

Size variation. Males vary from 6.2 to 6.7 in the body length, carapace $3.25-3.5$ long and 2.9-3.1 wide $(n=4)$. Females vary from 6.7 to 8.0 in the body length, carapace 3.05-3.5 long and 2.85-3.25 wide $(\mathrm{n}=8)$.

DISTRIBUTION. A few localities in Kuraisky and Chikhacheva Mt. Ranges of the mountain Altai.

BIOLOGY. The new species occurs in the highlands above $3000 \mathrm{~m}$ a.s.l. Females make white egg sacs about one centimeter in diameter which are attached to the underside of stones and guarded by the female (Fig. 6). Females with egg sacs were found in the late July.
Xysticus tyshchenkoi Marusik et Logunov, 1995 Figs 3-4, 10-12, 18-19.

Xysticus tyshchenkoi Marusik et Logunov, 1995: 150, figs 3439 ( $0^{3}+$; the type series from the ISEA, examined).

Xysticus sabulosus: Utochkin, 1968: 19, figs 110-112 (O'+, misidentified).

For a complete list of references see WSC [2015].

PARATYPES. KAZAKHSTAN: $30^{7} \sigma^{7}, 5$ ㅇ (ISEA, 000.329) from Kazakhstan, Jambyl (=Dzhambul) Region, Krasnogosk Distr., $37 \mathrm{~km}$ NE of Georgievka, near Kurday Pass, 13-14.06.1990, A.A. Fyodorov, A.A. Zyuzin; 2 우 (ISEA, 000.340), South Kazakhstan (=Chimkent) Region, Aksu-Dzhabagly, 10.07.1989, Abdibekov. TAJIKISTAN: $22 \sigma^{7} \sigma^{7}, 6$ 우 (ISEA, 000.331) Shakhristan District, Turkestan Distr., 20.06-01.07.1974, Yu. Lebedev.

DIAGNOSIS. This species is most similar to $X$. secedens L. Koch, 1876 (widespread in the Alps and 

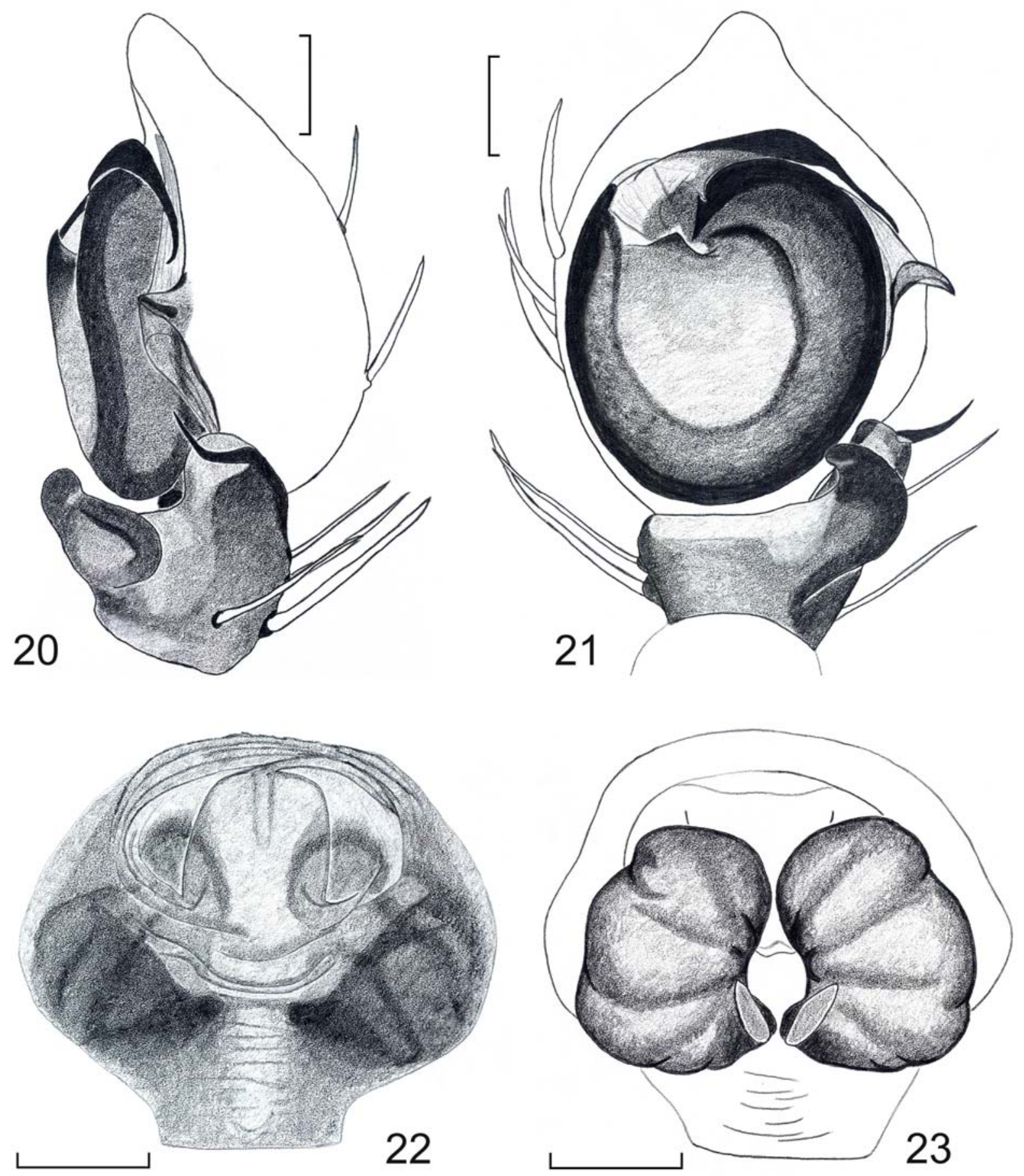

Figs 20-23. Copulatory organs of Xysticus novokhatskyii sp.n. 20-21 - male palp, retrolateral and ventral view; 22 - epigyne, ventral view; 23 - ditto, dorsal view. Scale $0.2 \mathrm{~mm}$.

Рис. 20-23. Копулятивные органы Xysticus novokhatskyii sp.n. 20-21 - пальпа самца, виды ретролатерально и вентрально; 22 эпигина, вид снизу; 23 - тоже, вид сверху. Масштаб 0,2 мм. 
the Balkans) and to the Palearctic X. sabulosus (Hahn, 1832) and differs from both of them in the embolic tip directed proximad (directed distad in $X$. secedens and $X$. sabulosus) and in the shape of tegular ridge in the male. The female of $X$. tyshchenkoi can be distinguished from those of both related species by the shape of receptacula and epigyne. $X$. tyshchenkoi differs from $X$. novokhatskyii sp.n. in having the convoluted embolic tip and the swollen retrolateral margin of the cymbium in the male and in the wide, U-shaped epigynal septum and the shape of receptacles in the female.

DISTRIBUTION. Widespread in Middle Asia: Kazakhstan, Kirghizia, Turkmenistan and Tajikistan [Marusik, Logunov, 1995].

\section{Xysticus mongolicus Schenkel, 1963}

Figs 5, 13-15.

X. mongolicus: Utochkin, Savelyeva, 1995: 67, figs 1A-G ( $\left(^{7}+\right)$

X. mongolicus: Song, Zhu, 1997: 95, figs 62A-D ( $\left.\sigma^{7}+\right)$.

$X$. mongolicus: Song et al., 1999: 503, figs 286G,P (O'O).

For a complete list of references see WSC [2015].

MATERIAL. RUSSIA: $1 \sigma^{7}$ (ISEA, 001.7769), Altai Republic, Kosh-Agach District, $6 \mathrm{~km}$ SE of Chagan-Uzun Vil. $\left(50^{\circ} 04^{\prime} \mathrm{N}\right.$, $\left.88^{\circ} 26^{\prime} \mathrm{E}\right), 1900 \mathrm{~m}$ a.s.1., stony semi-desert steppe, 26.07.2012, A.A. Fomichev. - KAZAKHSTAN: $2 \sigma^{7} \sigma^{7}$ (ISEA, 001.6911), Almaty Region, Bakanas Vil., botanical garden, 09.1988, E.V. Shikov; 1 フ, 2 우 (ISEA, 001.6910), East Kazakhstan Region, near Ust-Kamenogorsk Town, 09.1980, L.G. Savelyeva.

DISTRIBUTION. WSC [2015] reports this species from Kazakhstan, Mongolia and China. But actually, it has also been reported from southern part of European Russia [Ponomarev, Abdurakhmanov, 2014], Ukraine [Polchaninova, Prokopenko, 2013] and Azerbaijan [Guseinov, Rubtsova, 2001].

The species is recorded from the Russian Altai for the first time. This record is the first finding of $X$. mongolicus in the Asian part of Russia.

ACKNOWLEDGEMENTS. I wish to thank R.V. Yakovlev (Barnaul, Russia), S.Yu. Sinev (Saint Petersburg, Russia), Yu.A. Novokhatskyi, S.M. and E.M. Ayubaev (Aktash, Russia), A.V. Pershin (Biysk, Russia) and A.N. Nakonechnyi (Novosibirsk, Russia) for the help in organization of the field trips to the mountain Altai in which the material studied here was collected. Special thanks go to D.V. Logunov (Manchester, UK) for a fruitful discussion and to G.N. Azarkina (ISEA) for giving access to the comparative material from the ISEA. K.G. Mikhailov (ZMMU) and A.V. Ponomarev (Rostov-on-Don, Russia) are thanked for providing the information about current distribution of $X$. mongolicus. I also wish to thank R.Yu. Dudko (ISEA) for allowing me to use the ISEA facilities. The earlier draft was reviewed by G.N. Azarkina, D.V. Logunov and Yu.M. Marusik (Magadan, Russia).

\section{References}

Almquist S. 2006. Swedish Araneae, part 2-families Dictynidae to Salticidae // Insect Systematics \& Evolution. Supplement No.63. P.285-601.
Azarkina G.N., Trilikauskas L.A. 2013. New data on spider fauna (Aranei) of the Russian Altai, part III: families Mimetidae, Miturgidae, Oxyopidae, Philodromidae, Pholcidae, Pisauridae, Salticidae, Sparassidae, Tetragnathidae, Theridiidae, Thomisidae, Titanoecidae, Uloboridae and Zoridae // Euroasian entomol. J. Vol.12. No.3.P. 243-254.

Danilov S.N. 1993. Crab spiders (Aranei Thomisidae, Philodromidae) of Transbaikalia, $1 / /$ Arthropoda Selecta. Vol.2. No.1. P. 61-67.

Fomichev A.A., Marusik Yu.M., Koponen S. 2014. A new species of Xysticus C.L. Koch, 1835 (Aranei: Thomisidae) from South Siberia // Arthropoda Selecta. Vol.23. No.2. P.127-134.

Guseinov E.F., Rubtsova L.E. 2001. [Spider species (Arachnida: Araneae) new to the fauna of Azerbaijan] // Study and protection of the animal world on the end of century. Proceedings of the scientific conference dedicated to the 80th anniversary of Academician M.A. Musaev. Baku: Elm. P.236-239 [in Russian, with English summary].

Logunov D.V. 1995. Contribution to the northern Asian fauna of the crab spider genus Xysticus C.L. Koch, 1835 (Aranei Thomisidae) // Arthropoda Selecta. Vol.3. No.3-4. P.111-118.

Logunov D.V., Marusik Yu.M. 1994. A faunistic review of the crab spiders (Araneae, Thomisidae) from the mountains of South Siberia // Bull. Inst. Roy. Sci. Natur. Belgique, Entomologie. Vol.64. P.177-197.

Logunov D.V., Marusik Yu.M. 1998. A new species of the genus Xysticus from the mountains of South Siberia and Mongolia (Araneae, Thomisidae) // Bull. Br. arachnol. Soc. Vol.11. Pt.3. P.103-106

Logunov D.V., Marusik Yu.M., Koponen S. 1998. A check-list of the spiders in Tuva, South Siberia with analysis of their habitat distribution // Ber. nat.-med. Verein Innsbruck. Bd.85. S.125159

Marusik Yu.M. 1989. [Two new species of the spider genus Xysticus and synonymy of crab spiders (Aranei, Thomisidae, Philodromidae) from Siberia] // Zool. Zh. Vol.68. No.4. P.140-145 [in Russian, with English summary].

Marusik Yu.M., Logunov D.V. 1995. The crab spiders of Middle Asia 2 (Arachnida: Araneae: Thomisidae) // Beitrage Araneol. Bd.4. P.133-175.

Marusik Yu.M., Logunov D.V. 2002. New and poorly known species of crab spiders (Aranei: Thomisidae) from South Siberia and Mongolia // Arthropoda Selecta. Vol.10. No.4 P.315-322.

Marusik Yu.M., Logunov D.V., Koponen S. 2000. Spiders of Tuva, South Siberia. Magadan: IBPN FEB RAS. 252 pp.

Mikhailov K.G. 2013. The spiders (Arachnida: Aranei) of Russia and adjacent countries: a non-annotated cheklist // Arthropoda Selecta. Supplement No.3. 262 pp.

WSC 2015. World Spider Catalog, Version 15.5. Natural History Museum Bern; online at: http://wsc.nmbe.ch (accessed on January, 2015).

Polchaninova N.Yu., Prokopenko E.V. 2013. Catalogue of the spiders (Arachnida, Aranei) of Left-Bank Ukraine // Arthropoda Selecta. Supplement No.2. 268 pp.

Ponomarev A.V., Abdurakhmanov G.M. 2014. Spiders (Aranei) of North Caspian coast and islands // Yugh Rossii: ekologiya, razvitie. Vol.1. P.76-121 [in Russian, with English summary].

Simon E. 1895. Arachnides recueillis par M. G. Potanine en Chinie et en Mongolie (1876-1879) // Bulletin de l'Académie impériale des sciences de St.-Pétersbourg Vol.5. No.2. P.331-345.

Song D.X., Zhu M.S. 1997. Fauna Sinica: Arachnida: Araneae: Thomisidae, Philodromidae. Beijing: Science Press. 259 pp.

Song D.X, Zhu M.S., Chen J. 1999. The Spiders of China. Shijiazhuang: Hebei University of Science and Techology Publishing House. 640 pp.

Utochkin A.S. 1968. Pauki roda Xysticus fauny SSSR (Opredelitel'). Perm Univ. 73 pp. [in Russian]

Utochkin A.S., Savelyeva L.G. 1995. Review of the spider genus Xysticus C. L. Koch, 1835 (Arachnida Aranei Thomisidae) in the East Kazakhstan area // Arthropoda Selecta. Vol.4. No.1. P.65-69.

Responsible editor D.V. Logunov 